\title{
The effect of bypassing the rumen with supplements of protein and energy on intake of concentrates by sheep
}

\author{
By E. R. ØRSKOV, C. FRASER AND R. PIRIE \\ The Rowett Research Institute, Bucksburn, Aberdeen, $A B 2{ }_{9} S B$ \\ (Received 27 November 1972 - Accepted 23 February 1973)
}

\begin{abstract}
I. Two experiments were conducted with young early-weaned lambs to measure the voluntary intake of dry concentrates when additional protein or lactose was given as a fluid preparation from a bottle.

2. The voluntary intake of a barley-urea diet ( $130 \mathrm{~g}$ crude protein $/ \mathrm{kg}$ ) was increased by $10-15 \%$ as a result of giving $2.3 \mathrm{~g}$ nitrogen $/ \mathrm{d}$ as a fish-protein concentrate in fluid suspension. Amounts greater than $2.3 \mathrm{~g} \mathrm{~N} / \mathrm{d}$ did not further increase voluntary intake but increased growth rate and food conversion ratio. Urea given as a solution in water in the same way in amounts equivalent to $4.6 \mathrm{~N} / \mathrm{d}$ had no effect on voluntary intake.

3. The voluntary intake of a high-protein barley-fish-meal diet was decreased by giving ro or $20 \%$ of the estimated intake as lactose by bottle. The results indicated that maximum energy intake was achieved with the basal diet, since the decrease in energy intake was about equal to the amount given in the solution bypassing the rumen.
\end{abstract}

In recent years much effort has been directed towards elucidating the mechanisms regulating the voluntary intake of food by ruminants. With forage diets the voluntary intake is largely limited by physical distension of the forestomach, as recently discussed by Campling (I970). With concentrate diets, on the other hand, ruminants tend to adjust their intake to achieve a constant intake of digestible energy (Baumgardt, 1970). When the intake is regulated by physical distension, dry-matter intake increases with increasing digestibility, whereas the converse is true with concentrate diets. These are generalizations; the point, for instance, where one mechanism operates and another takes over is obviously not well defined and may be influenced by many factors such as animal species, particle size of the feed (Andrews, Kay \& Ørskov, I969) and the palatability of the diets (Greenhalgh \& Reid, I97I).

Observations which cannot be satisfactorily explained by either mechanism are those of Egan (1965) and Egan \& Moir (1965). They showed that infusion of casein into the duodenum increased the intake of a low-quality roughage diet by about $42 \%$ whereas infusion of an isonitrogenous amount of urea increased intake by only about $12 \%$. These observations were interpreted to suggest that the protein status of the animal had an effect on voluntary intake, since the effect of urea could be explained by an increase in the recycling of urea to the rumen with a consequent improvement in the rate of rumen fermentation.

In lambs given diets consisting of barley and fish meal, it was shown (Ørskov, Fraser, McDonald \& Corse, 1971) that voluntary intake increased when the protein concentration was increased from I $\mathrm{I}$ to $15 \%$ crude protein in the dry matter. It was difficult to explain this increase in intake. The effect could have been due either to changes in the rate of rumen fermentation or, according to Egan, to an improved 
protein status of the animal, for it had been shown by Ørskov, Fraser \& McDonald (197I) that fish meal added to a barley diet increased the amount of protein absorbed from the small intestine.

The experiments reported here were initiated to investigate the effect on the voluntary intake of barley-based diets of giving protein or lactose in solution, by bottle,

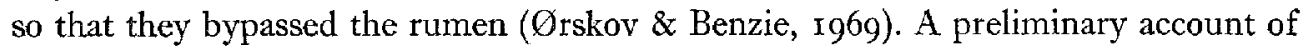
part of this work has been published (Ørskov, Fraser \& Corse, I97I).

\section{EXPERIMENTAL}

\section{Animals}

Expt $\mathrm{I}$. Ten male and ten female Suffolk $\hat{\delta} \times$ North Country Cheviot 9 lambs were used. They were weaned at $2-3$ weeks of age and taught to drink milk from a bottle fitted with a teat. Dry concentrate food and water were offered ad lib. At about $5_{5} \mathrm{~kg}$ live weight, when $6-7$ weeks of age, they were allocated to the experimental treatments.

Expt 2. Ten male Finnish Landrace $\hat{\partial} \times$ Dorset Horn $q$ lambs and ten female Suffolk $\delta \times$ (Finnish Landrace $\hat{t} \times$ Dorset Horn i) lambs were used. They were weaned and treated as for the lambs in Expt $\mathbf{r}$, and were allocated to the experimental treatments at a weight of between $I$ I and $I_{5} \mathrm{~kg}$.

\section{Design and treatments}

Expt $\mathrm{I}$. Two male and two female lambs were allocated at random to each of the five treatments shown below. All received, ad lib., a basal barley concentrate diet that contained (per $\mathrm{kg}$ ) $960 \mathrm{~g}$ rolled barley, $9 \mathrm{~g}$ urea, $\mathrm{I} 5 \mathrm{~g}$ dicalcium phosphate, $5 \mathrm{~g}$ limestone, ${ }_{1} \mathrm{O} \mathrm{mg} \mathrm{ZnSO}_{4} \cdot{ }_{7} \mathrm{H}_{2} \mathrm{O}, 80 \mathrm{mg} \mathrm{MnSO}_{4} \cdot{ }_{4} \mathrm{H}_{2} \mathrm{O}$, $0.43 \mathrm{mg} \mathrm{CoSO}_{4} \cdot{ }_{7} \mathrm{H}_{2} \mathrm{O}, 200 \mathrm{mg}$ $\mathrm{MgO}, \mathrm{I} \cdot 5 \mathrm{mg}$ retinyl palmitate, $0.025 \mathrm{mg}$ cholecalciferol and $20 \mathrm{mg}$ DL- $\alpha$-tocopheryl acetate. The diet, which was pelleted through a $7.7 \mathrm{~mm}$ die, contained $130 \mathrm{~g}$ crude protein $/ \mathrm{kg}$ dry matter. The lambs also received daily, by bottle, $500 \mathrm{ml}$ water containing a supplementary $\mathrm{N}$ source. Three of the treatment groups received different amounts of a fish-protein concentrate (FPC: Astra Nutrition, A. B. Mölndal, Sweden) containing $900 \mathrm{~g}$ crude protein/kg dry matter, namely $17 \mathrm{~g} \mathrm{FPC}(2.3 \mathrm{~g} \mathrm{~N}), 34 \mathrm{~g}$ FPC $(4.6 \mathrm{~g} \mathrm{~N})$ or $5^{\mathrm{I}} \mathrm{g} \mathrm{FPC}(6.9 \mathrm{~g} \mathrm{~N})$. The fourth group received ro $\mathrm{g}$ urea $\left(4^{\circ} 6 \mathrm{~g} \mathrm{~N}\right)$ and the controls were given no supplement in the water. The lambs were given the basal concentrate once daily in amounts estimated to be about $10 \%$ in excess of voluntary intake. The uneaten feed was recorded three times weekly and dried to constant weight at $100^{\circ}$. The liquid supplement was divided into four equal $125 \mathrm{ml}$ portions and given at $08.00,12.00,16.00$ and 20.00 hours from a bottle fitted with a teat.

Expt 2. In an initial period of 2 weeks the lambs were given $400 \mathrm{ml}$ cow's milk daily by bottle, and the voluntary intake of a basal, high-protein concentrate diet was measured. The basal diet consisted of (per kg) $840 \mathrm{~g}$ rolled barley, $\mathrm{I} 45 \mathrm{~g}$ white-fish meal and $\mathrm{I} 5 \mathrm{~g}$ limestone: it contained $\mathrm{I} 98 \mathrm{~g}$ crude protein $/ \mathrm{kg}$ dry matter. Apart from controls, the lambs were given supplements of lactose either in solution (by bottle) or as a solid incorporated into the barley - fish-meal diet. 
Four lambs (two males and two females) were allocated at random to treatments as follows.

\section{Feeding regimen}

I Barley - fish-meal diet given ad lib. (control)

2 Barley - fish-meal diet given $a d$ lib. with an estimated $10 \%$ of food intake as lactose by bottle

3 Barley - fish-meal diet given ad $l i b$. with an estimated $20 \%$ of food intake as lactose by bottle

4 Barley - fish-meal diet with 10\% lactose incorporated given ad lib.

5 Barley - fish-meal diet with $20 \%$ lactose incorporated given ad $7 i b$.

All lambs received daily from a bottle approximately $300 \mathrm{ml}$ water which contained the lactose when this was supplied in the liquid form. The amount of lactose to be given in the water by bottle was calculated by estimating the intake from the amount of concentrate consumed during the previous week and the times of feeding were the same as in Expt I. The concentrate was offered in a way similar to that adopted in Expt I. The all-solid diets contained: $100 \mathrm{~g}$ lactose and $900 \mathrm{~g}$ basal diet $/ \mathrm{kg}$; and $200 \mathrm{~g}$ lactose and $800 \mathrm{~g}$ basal diet $/ \mathrm{kg}$. The trace minerals and vitamins included were the same as for Expt $\mathrm{I}$ and all diets were pelleted through a $7.7 \mathrm{~mm}$ die.

For both experiments, fresh water was always freely available from a trough and the lambs were randomly allocated to individual pens and bedded with sawdust.

\section{Slaughter procedure}

When the lambs weighed about $45 \mathrm{~kg}$ (Expt I) or $40 \mathrm{~kg}$ (Expt 2) they were taken to the slaughter-house where the cold carcass weight and the weight of the carcasses immersed in water at about $7^{\circ}$ were recorded. For Expt 2, samples of rumen fluid were obtained immediately after slaughter. The proportions of volatile fatty acids were determined on acidified samples of rumen fluid by gas-liquid chromatography (Pye 104) with a flame ionization detector (Fell, Kay, Whitelaw \& Boyne, I968).

\section{RESULTS}

\section{Experiment I}

The lambs were in good health throughout the experiment and drank eagerly from the bottle at feeding times.

Daily feed intakes at given times were calculated from the slopes of graphs of cumulative feed intake against time. The live weights corresponding to these times were read from graphs where live weight was plotted against time. There was no significant correlation between initial weight and voluntary intake at subsequent weights. The effect of the treatments on the daily intake of the basal feed is given in Table I. At $25 \mathrm{~kg}$ live weight, treatment differences in voluntary intake were not statistically significant $\left(P<0^{\circ} \mathrm{I}\right)$. At $35 \mathrm{~kg}$ live weight, there was a rectilinear increase in voluntary intake with increasing amounts of supplementary protein $(P<0.05)$, the first increment having the greatest effect. At $45 \mathrm{~kg}$ live weight there was a curvilinear response to effects of protein supplementation $(P<0.01)$. Supplements of urea did not significantly improve intake of the basal diet at any live weight.

The effects of the treatment on growth rate and food utilization are given in Table 2. 
Table I. Expt 1. Daily intake of basal feed at various live weights by lambs receiving no supplement or given urea or increments of fish-protein concentrate $(F P C)$ in solution by bottle so that the rumen is bypassed

(Each value is the mean of four animals)

\begin{tabular}{lrcr} 
Supplement & \multicolumn{3}{c}{ Intake (g dry matter/d) } \\
\cline { 2 - 4 }$(\mathrm{g} / \mathrm{d})$ & $\begin{array}{c}25 \mathrm{~kg} \\
\text { live wt }\end{array}$ & $\begin{array}{c}35 \mathrm{~kg} \\
\text { live wt }\end{array}$ & $\begin{array}{c}45 \mathrm{~kg} \\
\text { live wt }\end{array}$ \\
None & $85 \mathrm{I}$ & 1078 & $\mathrm{1265}$ \\
I7 FPC & 994 & 1190 & $\mathrm{I4I5}$ \\
34 FPC & 927 & 1196 & $156 \mathrm{r}$ \\
5I FPC & 1003 & $124 \mathrm{I}$ & 1416 \\
I0 urea & 853 & 1062 & 1246 \\
SE of treat- & 48 & 44 & 43 \\
ment means & & &
\end{tabular}

Table 2. Expt r. Effect of giving urea or supplements of fish-protein concentrate (FPC) in solution by bottle so that the rumen is bypassed on growth rate and food conversion ratio by lambs from $\mathrm{I} 5$ to $45 \mathrm{~kg}$ live weight

(Each value is the mean of four animals)

\begin{tabular}{|c|c|c|c|c|c|c|}
\hline $\begin{array}{l}\text { Supplement } \\
\qquad(\mathrm{g} / \mathrm{d})\end{array}$ & $\begin{array}{l}\text { Initial wt } \\
\quad(\mathrm{kg})\end{array}$ & $\begin{array}{l}\text { Final wt } \\
(\mathrm{kg})\end{array}$ & $\begin{array}{l}\text { Growth wt } \\
(\mathrm{g} / \mathrm{d})\end{array}$ & $\begin{array}{l}\text { Food } \\
\text { conversion } \\
\text { ratio* } \\
\text { (kg dry } \\
\text { matter:kg } \\
\text { gain) }\end{array}$ & $\begin{array}{l}\text { Killing-out } \\
\text { percentage }\end{array}$ & $\begin{array}{l}\text { Specific } \\
\text { gravity of } \\
\text { carcasses }\end{array}$ \\
\hline None & 14.3 & $45 \cdot \mathbf{I}$ & 230 & $4 \cdot 29$ & $49 \cdot 8$ & $1 \cdot 048$ \\
\hline I7 FPC & I4.7 & $45 \cdot 5$ & 300 & 3.50 & $50 \cdot 6$ & $1 \cdot 049$ \\
\hline 34 FPC & 15.8 & $45 \cdot 7$ & 326 & $3 \cdot 22$ & $47 \cdot 3$ & $I \cdot 05 I$ \\
\hline 5 I FPC & 13.6 & $45^{\cdot} \cdot \mathrm{I}$ & 332 & 3.03 & $48 \cdot 2$ & $1 \cdot 055$ \\
\hline Io urea & 15.2 & 4477 & 224 & 4.28 & $50 \cdot 2$ & $I \cdot 052$ \\
\hline $\begin{array}{l}\text { SE of treat- } \\
\text { ment means }\end{array}$ & - & - & 22 & 0.21 & $\mathrm{I} \cdot 4$ & 0.005 \\
\hline
\end{tabular}

The growth rate increased rectilinearly $(P<0.01)$ and the food conversion ratio ( $\mathrm{kg}$ food $/ \mathrm{kg}$ gain) decreased rectilinearly $(P<0.00 \mathrm{r})$ with fish-protein supplementation. The first increment of protein had the greatest effect, but the quadratic component did not reach significance. There were no significant differences between the lambs given the unsupplemented diet and those given urea. The killing-out percentages were not significantly influenced by the treatments. There were no significant treatment effects on the specific gravities of the carcasses.

\section{Experiment 2}

All lambs completed the experiment in good health. Occasionally the lambs receiving $20 \%$ of their diet as lactose from the bottle showed signs of scouring which suggests that some of the lactose was fermented in the large intestine. In the statistical analysis, both the intake during the first 2 weeks and the initial weights were tested as 
'Table 3. Expt 2. Effect of giving 10 or $20 \%$ lactose in the concentrate compared with giving 10 or $20 \%$ of the estimated food intake as lactose in solution by bottle so that the rumen is bypassed on the voluntary food intake of lambs at 20, 30 and $40 \mathrm{~kg}$ live weight

\begin{tabular}{|c|c|c|c|c|c|}
\hline \multirow[b]{2}{*}{ Supplement } & \multicolumn{3}{|c|}{$\begin{array}{l}\text { Concentrate intake } \\
\text { (g dry matter } / \mathrm{d})\end{array}$} & \multicolumn{2}{|c|}{$\begin{array}{c}\begin{array}{c}\text { Mean daily intake of } \\
\text { dry matter }(\mathrm{g} / \mathrm{d})\end{array} \\
\end{array}$} \\
\hline & $\begin{array}{l}20 \mathrm{~kg} \\
\text { live wt }\end{array}$ & $\begin{array}{l}30 \mathrm{~kg} \\
\text { live wt }\end{array}$ & $\begin{array}{l}40 \mathrm{~kg} \\
\text { live wt }\end{array}$ & Consumed & $\begin{array}{l}\text { Including } \\
\text { lactose } \\
\text { given from } \\
\text { bottle }\end{array}$ \\
\hline $\begin{array}{l}\text { None } \\
\text { ro\% of intake as lactose } \\
\text { (from bottle) }\end{array}$ & $\begin{array}{l}713 \\
680\end{array}$ & $\begin{array}{r}1077 \\
950\end{array}$ & $\begin{array}{l}1317 \\
1083\end{array}$ & $\begin{array}{l}936 \\
838\end{array}$ & $\begin{array}{l}936 \\
939\end{array}$ \\
\hline $\begin{array}{l}20 \% \text { of intake as lactose } \\
\text { (from bottle) }\end{array}$ & $63^{\circ}$ & 925 & 945 & 757 & 919 \\
\hline $\begin{array}{l}10 \% \text { lactose (in concentrate) } \\
20 \% \text { lactose (in concentrate) }\end{array}$ & $\begin{array}{l}780 \\
740\end{array}$ & $\begin{array}{r}935 \\
1045\end{array}$ & $\begin{array}{l}1203 \\
1128\end{array}$ & $\begin{array}{l}947 \\
868\end{array}$ & $\begin{array}{l}947 \\
868\end{array}$ \\
\hline SE of treatment means & 47 & 24 & 60 & 50 & 50 \\
\hline
\end{tabular}

Table 4. Expt 2. Effect in lambs on food conversion ratio of incorporating 10 or $20 \%$ lactose in the concentrate compared with giving ro or $20 \%$ of the estimated food intake as lactose in solution by bottle so that the rumen is bypassed

(Each value is the mean of four animals)

\begin{tabular}{|c|c|c|c|c|c|c|}
\hline Supplement & $\begin{array}{l}\text { Initial wt } \\
\quad(\mathrm{kg})\end{array}$ & $\begin{array}{l}\text { Final wt } \\
\quad(\mathrm{kg})\end{array}$ & $\begin{array}{c}\text { Growth } \\
\text { rate } \\
(\mathrm{g} / \mathrm{d})\end{array}$ & $\begin{array}{c}\text { Food } \\
\text { conversion } \\
\text { ratio } \\
\text { (kg dry } \\
\text { matter: kg } \\
\text { live-wt } \\
\text { gain) }\end{array}$ & $\begin{array}{l}\text { Killing- } \\
\text { out per- } \\
\text { centage }\end{array}$ & $\begin{array}{c}\text { Specific } \\
\text { gravity of } \\
\text { carcasses }\end{array}$ \\
\hline None & $17 \cdot 1$ & $4 I \cdot 2$ & $3 I 3$ & 3.14 & $46 \cdot 6$ & 1.050 \\
\hline $\begin{array}{l}\text { I0 } \% \text { of intake as lactose } \\
\text { (from bottle) }\end{array}$ & $15^{*} \mathrm{I}$ & 40.5 & 325 & $2 \cdot 95$ & $49 \cdot 0$ & 1.053 \\
\hline $\begin{array}{l}20 \% \text { of intake as lactose } \\
\text { (from bottle) }\end{array}$ & 13.5 & $40 \cdot I$ & 269 & $3 \cdot 36$ & $49 \cdot 6$ & $r \cdot 05^{\circ}$ \\
\hline $10 \%$ lactose (in concentrate) & $14^{\cdot 8}$ & $40 \cdot 2$ & 292 & 3.36 & $49 \cdot 6$ & $\mathbf{r} \cdot 048$ \\
\hline $20 \%$ lactose (in concentrate) & 15.5 & $40 \cdot 1$ & 260 & $3 \cdot 36$ & 49.5 & I.044 \\
\hline SE of treatment means & & & 18 & 0.16 & $\mathbf{r} \cdot 0$ & 0.004 \\
\hline
\end{tabular}

covariates, but no significant reduction in the residual standard deviations was achieved. The effects of treatment on intake are given in Table 3 . At $20 \mathrm{~kg}$ live weight, the differences between treatments in the voluntary food intake were not significant; however, both at 30 and at $40 \mathrm{~kg}$ live weight, the voluntary intake decreased rectilinearly $(P<0.001)$ with the percentage of the diet given as lactose by bottle. Lactose included in the dry food did not cause significant reductions in intake except at $40 \mathrm{~kg}$ live weight when intake was reduced on the diet containing $20 \%$ lactose $(P<0.05)$, and at $30 \mathrm{~kg}$ when the diet contained $10 \%$ lactose. The general mean intake decreased rectilinearly $(P<0.01$ ) with percentage of the diet given as lactose from the bottle and there was no significant effect when lactose was included in the dry food. If the 
weight of the lactose which had been given from the bottle was added to the intake of concentrate there was no longer any significant effect of treatment.

The initial and final live weights of the lambs and food conversion ratio are given in Table 4. There were no significant effects of the treatments on either growth rate, food conversion ratio, killing-out percentage or the specific gravity of the carcass. The proportion of the volatile fatty acids in the rumen did not alter significantly with treatment. The mean molar proportions $(\%)$ were acetic acid $50 . \mathrm{I}$, propionic acid $29^{\circ} 6$, isobutyric acid $\mathbf{I} \cdot 8$, butyric acid $I_{3} \cdot 1$, isovaleric acid $2 \cdot 0$, valeric acid $2 \cdot 3$, and caproic acid I.I.

\section{DISCUSSION}

\section{Effect of protein supplementation on the voluntary intake}

The results of Expt I showed that when a basal diet was given which contained I $30 \mathrm{~g}$ crude protein $/ \mathrm{kg}$, an amount which supplies sufficient nitrogen for the microbial fermentation of barley diets (Ørskov, Fraser \& McDonald, 1972), food intake was increased when protein was given in such a way that it bypassed the rumen. This increase in intake is unlikely to have been due to an increased recycling of $\mathrm{N}$ through blood and saliva to the rumen since urea given by bottle had no effect, and it must be concluded that the effect noted was due to an improved protein status of the animal. It seems, therefore, that the increase in intake observed when fish meal was included in a similar diet (Ørskov, Fraser, McDonald \& Corse, I97I), as referred to earlier, was due to an improved protein status of the animals as well, since part of the fish meal has been found to escape degradation in the rumen (Ørskov, Fraser \& McDonald, 197I). This work thus confirms recent observations by Weston (197I) who found an increased intake when formaldehyde-treated casein was added to a lucerne diet.

The experiment does not however give information on the causal mechanisms, but the additional protein probably enables the animal to metabolize nutrients at a greater rate. It is not known whether a similar effect could be produced in animals whose protein requirement was equal to or lower than the amount of microbial protein produced by the fermentation of the basal feed.

The effect noted has points of similarity with the original observations of Egan ( 1965$)$ and Egan \& Moir (1965) who found an increase in the voluntary intake of a lowprotein roughage diet when casein was infused through the duodenum. These Australian workers, however, used a low-protein roughage diet, whereas the concentrate diet used here contained $13 \circ \mathrm{g}$ protein $/ \mathrm{kg}$ so that the experiments differed in both the protein content and the digestibility of the diets. Secondly, the animals used by Egan were mature, which means that their requirements for protein would be very low. In the present work the lambs were consuming food at between two and three times their maintenance level and they were $2-4$ months old. 


\section{Effect of protein supplementation on food utilization}

The effect of protein supplementation on intake was mainly confined to the lowest increment of supplementation after which there was little or no further increase. There were, however, further small effects on growth rate and conversion of food which were not significant.

\section{The effect on intake of giving lactose in solution}

The protein content of the high-protein barley diet used in Expt 2 was estimated from previous experience to give maximum intake even when 10 or $20 \%$ lactose was included in the diet. The reduction in intake observed when lactose was given so that the rumen was bypassed clearly indicates that about the maximum intake was achieved on the basal diet. The reduction in intake of basal feed was about equal to the amount supplied through the rumen bypass, consequently there appears to be little benefit in supplementing in this way so far as intake is concerned when basal feeds are given which do not impose physical limitation on intake. The effect of supplementation in this way when roughages are given is at present being investigated.

The net utilization of the lactose given in solution may be expected to be superior to that of the lactose consumed with concentrate since losses due to fermentation in the rumen are avoided. With the $20 \%$ level of substitution the capacity for digestion in the small intestine might have been exceeded since the consistency of the faeces was sometimes affected in a way that suggested excess fermentation in the large intestine (Ørskov, Fraser, Mason \& Mann, I970).

The authors thank Mr I. McDonald for the statistical analysis of the results, $\mathrm{Mr}$ J. C. Gill and the Metabolic Staff for the care of the experimental animals and $\mathrm{Mr}$ R. S. Reid for the volatile fatty-acid analysis.

\section{REFERENCES}

Andrews, R. P., Kay, M. \& Ørskov, E. R. (1969). Anim. Prod. r1, r73.

Baumgardt, B. R. (I970). In Physiology of Digestion and Metabolism in the Ruminant p. 235 [A. T. Phillipson, editor]. Newcastle upon Tyne: Oriel Press.

Campling, R. C. (1970). In Physiology of Digestion and Metabolism in the Ruminant p. 226 [A. T. Phillipson, editor]. Newcastle upon Tyne: Oriel Press.

Egan, A. R. (1965). Aust F. agric. Res. r6, 45 I.

Egan, A. R. \& Moir, R. J. (1965). Aust f. agric. Res. r6, 437.

Fell, B. F., Kay, M., Whitelaw, F. G. \& Boyne, R. (I968). Res. vet. Sci. 9, 458.

Greenhalgh, J. F. D. \& Reid, G. W. (1971). Br. F. Nutr. 26, 107.

Ørskov, E. R. \& Benzie, D. (1969). Br. F. Nutr. 23, 415.

Ørskov, E. R., Fraser, C. \& Corse, E. L. (I97I). Proc. Nutr. Soc. 30, 25 A.

Ørskov, E. R., Fraser, C., Mason, V. C. \& Mann, S. O. (1970). Br. F. Nutr. 24, 67 I.

Ørskov, E. R., Fraser, C. \& McDonald, I. (I97I). Br. $\mathcal{F}$. Nutr. 25, 243.

Ørskov, E. R., Fraser, C. \& McDonald, I. (I97z). Br. F. Nutr. 27, 49 I.

Ørskov, E. R., Fraser, C., McDonald, I. \& Corse, E. L. (197r). F. agric. Sci., Camb. 77, 35 I.

Weston, R. H. (1971). Aust. F. agric. Res. 22, 307. 